\title{
Lexico-schematic Analysis of the Representation of Political Protests in Egypt in The New York Times and Ahramonline
}

\author{
Mohamed El-Nashar \\ College of Language and Communication, English \& Translation Department, \\ Arab Academy for Science, Technology and Maritime Transport, Cairo \\ melnashar68@gmail.com
}

Iman Madbouly

College of Language and Communication, Languages Department, Arab Academy for Science, Technology and Maritime Transport, Cairo manno505@hotmail.com

\begin{abstract}
This study aims at conducting a contrastive qualitative and quantitative analysis of the representation of the protests that took place in Egypt after late President Mohamed Morsi's November 2012 Constitutional Declaration, as reported by the U.S. The New York Times and Egyptian Ahramonline electronic newspapers. The significance of this research resides in the fact that, despite the elapse of about a decade on such watershed event, it has hitherto paid no linguistic attention. Discussion will draw on Critical Discourse Analysis, particularly Fairclough's (1995a) Discourse Analysis Model, and van Dijk's (1988) notion of News Schemata. We explore the similarities/differences in the representation of the event in the electronic newspapers both lexically and schematically with the aim of describing the function of language as a powerful socio-political practice in media discourse. The textual and discursive structure of 48 news reports were compared and related to the political and social context of the events to exhibit the newspapers' ideological strategies through various linguistic choices. The findings of the study exhibited more similarities than differences between the two newspapers. Up to 11 ideological strategies were detected in the analysis.
\end{abstract}

Keywords: Critical Discourse Analysis, Media Discourse, News Schemata, Constitutional Declaration, Protests in Egypt, Ideology 


\section{Introduction}

In the last few decades, people have become increasingly involved in local and international political action. News reporting, as a genre of media, has gained a lot of attention. Based on the belief that news reports can have an impact on shaping opinions and conveying ideologies, the present study attempts to investigate the function of language as a powerful tool in media discourse, more specifically, the news reports. The primary objective of the study is to critically analyze the similarities and differences in the linguistic lexical and schematic features used in the news reports under investigation. This is done to gain more understanding of journalistic media practices to ensure factual or presumed objectivity and transparency and to help understand how a political event is communicated linguistically.

On the 25th of January 2011, the Egyptian people launched a revolution against President Hosni Mubarak who had ruled Egypt for 30 years. The revolution resulted in ousting President Hosni Mubarak and the election of President Mohamed Morsi who belonged to the Muslim Brotherhood group. Five months after his election; more specifically, On the $22^{\text {nd }}$ of November, 2012, President Morsi issued a constitutional declaration which was seen by his Muslim Brotherhood as a means of protecting his powers. Many segments in the Egyptian society, however, regarded it as a means of wielding tyrannical power because, according to Ahramonline 22 November 2012, it immunized the People's Assembly and Shura Council (the two chambers of the Egyptian parliament) from dissolution and gave the President the right to take actions to protect the country and the goals of the Revolution without opposition. The Constitutional Declaration sparked off massive protests, resulting in violent clashes between the President's supporters and opponents.

Thus, we thought that the language used in representing these protests by foreign and national newspapers is worth investigating for various reasons. First, the protests were the first to take place after the election of the first President following the January, 2011 events and the ouster of late President Hosni Mubarak who had ruled Egypt for 30 years. Second, the Egyptian people who were unified during the January events were then split into supporters and opponents of President Morsi and his Constitutional Declaration. Finally, these protests have resulted in violent clashes which, in turn, led to deaths and hundreds of injuries - and were the casus belli of the 2013 events that culminated in Morsi's ouster. Examination of such reports will be conducted from a Critical 
Discourse Analysis framework, which we believe is a transdisciplinary field that can be useful in political communication.

Given the importance of language in general, and Critical Discourse Analysis in particular, in dissecting news reporting, framing, agenda setting, and content analysis, the perspective of this paper is believed to be by no means extraneous to the basic issues constituting the crux of the political communication field. Nimmo (1990) argues that one of the main goals of political communication research is to tackle the "consequences of the messages that constitute 'political communication"' (p. 116). We believe that a discursive analysis of what we might call the "triggers of the message," i.e. how and why it is written in a specific way, its lexical choices and implications as well as its schematic structure, is equally important. This symbiotic relationship between language and communication is demonstrated by many scholars (See, for example, Moon 2021, Pan \& Kosicki 1993, Shmargad, \& Klar 2020, van Dijk 1983). According to van Dijk (1991), Discourse Analysis emerged as a new "transdisciplinary' field of study" between the mid-1960s and mid-1970 (p. 108). Being eclectic in nature, CDA can be imbricated into the texture of different media fields. Applying such approach to dealing with news covering politically motivated protests, this study is hoped to afford yet another line of research to the interdisciplinary field of political communication with its different ramifications.

The data of this paper are 48 written online news reports selected from two newspapers of the highest circulation, The New York Times (US), a largely liberal paper, and Ahramonline (Egypt), a state-owned, conservative paper. They are analyzed to investigate the ideological strategies employed in the discursive representation of the protests that occurred in Egypt after the November 2012 presidential Constitutional Declaration. The aim is to examine whether the cultural diversities between the selected newspapers can result in discrepancies in the coverage of the same news event. An attempt is also made to show how the linguistic choices made by the newspapers influenced by their viewpoints vis-à-vis the events can have an impact on shaping the perception of the readers who receive the propositions from news reports as factual and indisputable. This pinpoints the inextricable link between discourse and ideology.

The relation between discourse and ideology is highlighted by Wodak (2006) who states: "Discourse is the place where language and ideology meet, and discourse analysis is the analysis of ideological dimensions of language use" (pp.16-17). An important subtype of discourse is news discourse which is a social 
action that can be used to serve a defined social purpose such as ideological dissemination (Chouliaraki, 2008). That is why we chose to employ a linguistic analysis of news reports, as it offers a clear interpretation of ideological factors latent in the data. It also sheds light on how different texts "encode values and ideologies that impact on and reflect the larger world," (Cotter, 2001, p.416). Such interpretation is described by Fowler and Kress (1979) as "a process of recovering the social meanings expressed in discourse by analyzing the linguistic structures in the light of their interactional and wider social context" (p.196). This, in turn, will result in informing the readers as to how powerful and influential journalistic language can be and how this power is implied in different news reports (Richardson, 2007).

Therefore, it is the role of Critical Discourse Analysis to raise consciousness about language (Fairclough \& Wodak, 1997) and to equip readers with the different linguistic tools that will help them "demystify" discourses by "deciphering ideologies" (Wodak 2006:4) from "ideologically laden texts" (Fowler, 1996:6). Analyzing the linguistic structures and different strategies of discourse, and placing them in their social and cultural contexts, will subsequently "unlock the ideologies and uncover the social meanings expressed in discourse" (Teo, 2000, p.11). Such endeavor is exigent in view of the implicit nature of ideology.

While Eggins (2004, p.9) rightly states that "...no text is free of ideology," scholars agree on the necessity for ideologies to be implicit in discourse in order to be more effective. For example, Fairclough (1989, p.85) points out that "ideology is most effective when its workings are least visible." Similarly, Retzlaff and Gänzle (2008, p. 69) state that "... ideologies are rather implicit or implied components of a text" and that putting texts into their socio-cultural and socio-political contexts can help reveal their ideology.

\section{Literature Review}

Since the 1970s, huge amounts of research have been conducted in the area of media discourse in general and news discourse in particular. Many of them make great use of the different tools provided by Critical Discourse Analysis (CDA) in order to reveal implicit power relations and ideologies in the analyzed texts. Although many studies focused on the area of news reporting, none of them tackled the foreign and Egyptian media representation of the protests that followed President Morsi's Constitutional Declaration. We believe, therefore, that this paper fills in a gap in research in this particular area. 
Being eclectic in nature, Critical Discourse Analysis has been widely used by many scholars to investigate different social, political, economic, racial, gender or religious issues in news reports (Ideological construction of racism in news: Teo 2000; representation of immigrants: Cabaniss 2006, Paulin 2007; negative racial discrimination against minorities: Hall, 2008; negative representation of religious differences: Sian, Law \& Sayyid 2012, Yusha'u 2012; practice of violence against women: Molek-Kozakowska (2012), Tranchese \& Zollo 2013; political representations: Al-Humaidi 2013, AlMustafa 2016, Bhatia 2006, Bharthapudi 2012, Bichang'a \& George 2012, Hasan 2016, Kim 2014, Lean 2008, Moftah 2013, Pasha 2011, Sheyholislami 2001, Youssef 2012). Almost all studies showed that news reporting is not a neutral process of representing facts. A narrower ramification of Critical Discourse Analysis is the discourse of protests, to which this current study also belongs.

Since discourse is 'an important dimension of everyday protest' (Riggins, 1990: p. 399), it has been an endogenous factor in grievances of almost all types (political protests, cuts in pay, price rises, suppression, dominant vs. dominated groups, gender issues, environment, etc.). The discourse of protest, which is a type of political discourse, has gained the attention of many critical discourse analysis scholars (e.g. Chilton, 2004; Wodak, 1989; van Dijk, 1998) been tackled from various lens (media positioning of protesters: Bassiouney, 2012; Davies \& Harré,1990; frames of interpretation of the protest signs: Said \& Kasanga, 2016; narrative construction of media sourcing: Ghobrial \& Wilkins, 2015; mobilization and political opportunity: Farmanfarmaian, 2014; and pragma-discursive analysis of political protests of students demonstrating over planned rises in university tuition fees, Hall, 2012). Relevant research of the discourse of protests is inextricably linked to the vast literature on the discourse of social movements, particularly the language of protest (Kumar, 2001; Sonntag, 2003;) in labour (Wood, 2000; Woolfson, 2006), environment (Linke, 2008), women's (Ukeje, 2004) movements.

This study is different in that it is the first to analyse the discourse of prerevolutionary protests sparked by late President Mohamed Morsi's Constitutional Declaration. Adopting a micro-/macro, lexico-schematic level of analysis was not preceded in any of the studies we came across and was helpful in reaching our findings. Despite such plethora of CDA studies and their ramifications, no study - to the best our knowledge - tackled President Morsi's Constitutional Declaration and the ensuing protests outside the presidential palace. By choosing this topic, 
we hope that it would fill in a gap in studying the foreign and national electronic newspaper representations of this watershed event.

\section{Methodology and Data Collection 3.1 Description of the Sample}

News reports are collected from the official websites of two newspapers; The New York Times and an Egyptian newspaper (Ahramonline). The analysis is confined to one news report per day selected from each of the newspapers covering the time span of 24 days between November 22, 2012 - the day of the Constitutional Declaration - and December 15, 2012 - the first day of the constitutional referendum. The total number is 48 reports, all available in the newspapers' online archives (See Appendix).

The news reports were retrieved from the online archive of these newspapers through several searches based on specific keywords. They were gathered from each of the two newspapers by keywords that include the following terms: Egyptian (constitutional declaration, protests, protesters, presidential palace protests, demonstrations, demonstrators, clashes, fights).

All reports were later evaluated for their direct relevance; articles that partially covered or briefly mentioned the events were discarded. Due to the fact that the news event occurred in Egypt, the number of articles in Ahramonline far exceeded those in The New York Times. Thus, one article was randomly selected for each day from the Egyptian newspaper. This resulted in 24 reports in each of the two newspapers under investigation.

The reason for choosing news reports to be the focus of this study is that they are generally regarded to be more informative, objective and factual than other types of articles in which opinions and stances are expressed more explicitly such as op-eds or opinion articles. However, such informativeness does not preclude the fact that news reports cannot be completely neutral or unbiased. That's why it is believed that "the world of the press is not the real world, but a world skewed and judged" (Fowler, 1991, p.11). Analysts believe that their responsibility falls in exposing the seemingly objective news reports in order to reveal the misrepresentations and obscurations that might pass unnoticed without their analysis (Schroder, 1994).

The New York Times and Ahramonline have been chosen for analysis as they are reputable daily newspapers of high journalistic standards. Besides having large circulations both domestically and internationally, they are available online in English, so that a linguistic comparison becomes feasible. 


\subsection{Research Questions and Analytical Framework}

The overarching research question that guides the present study is as follows: What are the differences/similarities between foreign and national newspapers sampled by The New York Times (USA) and Ahramonline (Egypt) in representing the protests in Egypt after the Presidential constitutional declaration and what are their implications?

This general guiding question can be broken down into the following specific sub-questions:

a) What are the lexical variations used to label the news actors and events?

b) How does the organization of the schematic structure of the reports signal particular ideological standpoints by the two newspapers?

In order to answer the research questions above, two CDA approaches intersect in our proposed framework in order to capture how the 2012 protests are linguistically portrayed in the selected newspapers. The framework combines Fairclough's (1995a) Discourse Analysis Model, and van Dijk's (1988) notion of Superstructure (news schemata). This micro-macro analytical framework has been specifically chosen as it believed to be capable of tackling the representation of reality exhibited in news reports. That is because many scholars tend to argue that news reports are not a simple reflection of reality; they are rather presented from a particular perspective according to the interests of the newspaper. This "representation" of reality is done for ideological purposes and can be achieved through various steps through the manipulation in lexical and schematic aspects of news reports (Fowler 1991, Kim 2014, Kress \& Hodge 1979).

Fairclough's (1995b) Discourse Analysis Model conceptualizes discourse in terms of three main dimensions; namely, text analysis, discourse practices and sociocultural practices. He argues that textual analysis should focus on the linguistic features of the text, which means the analysis of vocabulary, and the organization and the overall structure of the text. Being interested in the process of production by newspapers and consumption by readers, the second dimension, discourse practices, goes beyond the scope of this research. The third dimension, socio-cultural practices, investigates the social and political context (of the protests) to relate text to context and provide an explanation of media discourse during the period under investigation. We concur with Richardson (2007, p. 37) who describes Fairclough's Discourse Analysis Model for CDA as "...a more accessible method of doing CDA than alternative theoretical approaches" because 
this framework can be applied to studies relevant to media, political communication and society. Blommaert and Bulcaen (2000) argue that Fairclough's discursive approach acts as a "synthesis of a linguistic method of analyzing discourse as well as the political commitment that has become the trademark of CDA" (p.454). This micro-level analysis will be complemented with the second macro-level tool of analysis - van Dijk's (1988) notion of Superstructure (news schemata).

The analysis of the news reports schematic structure traces the flow of information and the order of events and topics (i.e., macro-propositions) in accordance with the different formal categories in news reports described by van Dijk (1988) and Fairclough (1995a). This type of analysis is particularly important in understanding the text's overall macrostructure. Schematic structure seeks to reveal the interaction between language and context "by looking beyond the formal structures of language as an abstract system" (Fowler, 1996, p.10). The schematic structure is organized in the form of an "inverted pyramid" and is arranged according to the "relevance principle" suggested by van Dijk (1988). Thus, the most important and newsworthy information from the newspapers' ideological standpoint is located at the top of the news report and the least important lies at the bottom. van Dijk (1988) and Fairclough (1995a) identify five major formal categories of news reports which are the Summary/Nucleus (headline + lead), Main Events, Background (context + history), Consequences (verbal reactions), Conclusion/Wrap up (evaluations + expectations). The present analysis, however, focuses on only four aspects that are considered the most revelatory of the newspapers' ideological standpoint. These categories are the summary, main events, background and evaluation.

\section{Discussion and Results}

In this section, the data under investigation will be analyzed lexically and schematically.

\subsection{Lexical Analysis}

According to Richardson (2007) "... words convey the imprint of society and of value judgments in particular - they convey connoted as well as denoted meanings" (p. 47). Analyzing lexical choices is considered one of the most important tools clarifying newspapers' overall construction of meaning. Fairclough (1989) argues "a text's choice of wording depends on, and helps create, social relationships between participants" (p. 116). In a similar vein, Mayr (2008) sees that the selection of vocabulary or lexical items "whether seemingly neutral 
or emotionally loaded, signals the speaker's or writer's attitude about a certain topic" (p. 21). This tool of analysis deals with investigating the connotations of the lexical choices that are used to refer to the major news actors and events in the period subject to the analysis. In addition, patterns of co-occurrence between words (i.e., nominal/adjectival collocations) are also examined as they present another level of meaning that helps discern the newspapers' perspective for evaluating the actors and events and the various strategies adopted in their representations of reality which directly influence the readers' perception.

Three major news actors are identified. They are Egyptian President Mohamed Morsi, his supporters and his opponents. Two important news events are also identified; namely, the Constitutional Declaration, and the protests it triggered.

In this context, we have detected the following ideological strategies employed in the data:

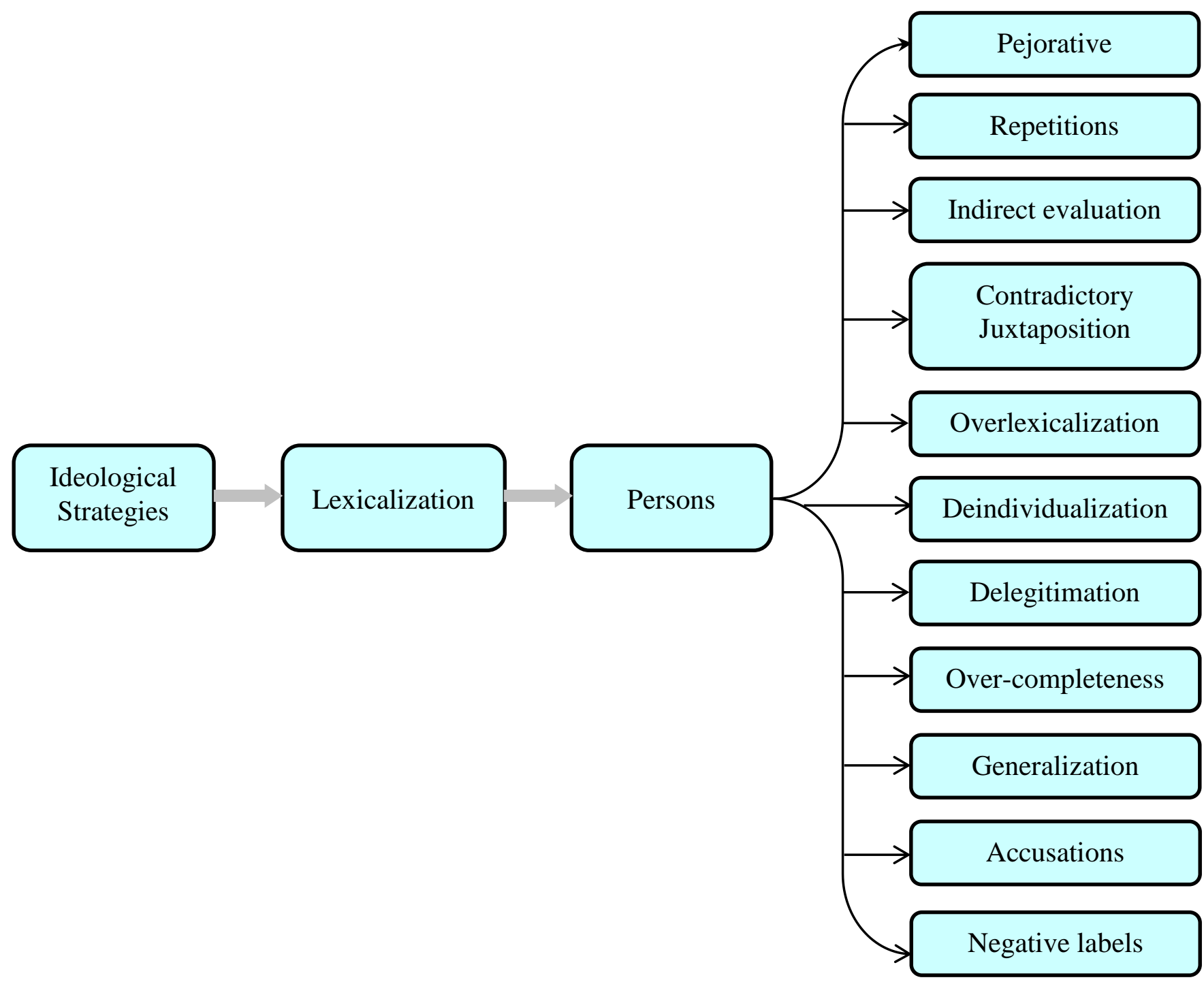

Figure 1. Ideological Strategies Detected in the Lexical Analysis 


\subsubsection{Reference to Major News Actors}

This section will analyze the three major news actors: Egyptian President Mohamed Morsi, his supporters and his opponents.

4.1.1.1 President Mohamed Morsi. The lexical references to President Mohamed Morsi in the news reports can be grouped into four main categories.

\begin{tabular}{lccccccccc}
\multicolumn{2}{c}{ Formal/Neutral } & \multicolumn{2}{c}{ Informal/Negative } & \multicolumn{2}{c}{ Ideological } & \multicolumn{2}{c}{ Freely } \\
Newspaper & & & & & \multicolumn{2}{c}{ Background } & \multicolumn{2}{cl}{ elected } \\
& No. & $\%$ & No. & $\%$ & No. & $\%$ & No. & $\%$ \\
New York Times & 244 & $88.72 \%$ & 10 & $4.23 \%$ & 13 & $4.72 \%$ & 8 & $2.90 \%$ \\
Ahramonline & 157 & $84.8 \%$ & 7 & $3.8 \%$ & 15 & $8.1 \%$ & 6 & $3.8 \%$
\end{tabular}

\section{Table 4.1 Labeling of President Mohamed Morsi in The New York Times and Ahramonline Reports}

To contextualize the above figures, it is important to cite examples about the four categories. First, The New York Times showed the highest frequency in Formal/Neutral category: "Egypt's President," "Egypt's leader," "Egyptian President," "President Mohamed Morsi," "Mr. Morsi, the President." Informal/Negative category was represented in: "the guardian of Egypt's revolution" (pejorative), "a protector of the revolution and a fledgling democracy" (pejorative), "a new strongman," "a pharaoh," "Mr. Morsi, who already governs without a legislature," "the embattled President, "Mohamed Morsi," and "a dictator." Ideological Background showed itself in: "Mr. Morsi, a former leader of the Muslim Brotherhood," "Mr. Morsi, an Islamist and Egypt's first elected President," "The country's new Islamist leader." Examples adduced about the fourth Freely Elected category are: "Mr. Morsi, the country's first freely elected leader," and "Mr. Morsi, Egypt's first democratically elected president." On the other hand, Formal/Neutral category in Ahramonline signaled the highest frequency and contained the same examples mentioned in the other paper. The Informal/Negative examples in Ahramonline are: "(Egypt's) new pharaoh," "an Islamist dictator," "Mohamed Morsi Mubarak" (linking him to his ousted predecessor), "the sovereign of the state" (pejorative).

Both newspapers are cautious when dealing with the Egyptian President. They frequently avoid the use of direct positive or negative labels to describe him and abide by the formality and objectivity rules in referring to the President in the highest frequency $(88.72 \% N Y T)$ and $(84.8 \% A O)$ with official position, proper 
name, honorifics, and last name, which are all considered as formal/neutral labels. However, the newspapers stress three important aspects when referring to the Egyptian President and utilize the repetition technique to highlight these qualities and thus shape the readers' views about him.

Firstly, both newspapers highlight the fact that the Egyptian President was a former leader of the Muslim brotherhood with a frequency of (4.72\% NYT) and (8.1\% AO). The same group is viewed by the NYT in (Report 24) as "a group the United States shunned for decades as a threat to western values and interests." The use of repetition is not probably intended to inform the readers of the Egyptian President's ideological background but rather to orient their attitude away from directly siding with the Egyptian President and his decisions.

Secondly, both newspapers adopt a strategy of indirect evaluation through other people's words by choosing to promote the voices of external commentators who tend to label the President with informal attributions. The newspapers find these labels which are negative and disrespectful to be newsworthy (4.23\% NYT) and $(3.8 \% A O)$. Thirdly, the newspapers identify the President as the first freely and democratically elected President in the Egyptian history with a frequency of $(2.90 \% N Y T)$ and $(3.8 \% A O)$. A plausible interpretation of this category, however, is that the labels "freely" and "democratically" are chosen strategically to collocate with the Egyptian President since they are juxtaposed with the content of his first constitutional declaration that is viewed by both newspapers as "power grab." We might call this strategy "contradictory juxtaposition." The following examples are chosen to provide context to some of the lexical labels that are used to refer to the Egyptian President (italics and boldface are added):

1. "I don't mind being on their side to oust $\boldsymbol{a}$ dictator," she said, speaking of $\mathbf{M r}$. Morsi. (NYT Report 6)

2. I know he's an elected President, but I think he lost his legitimacy. (AO Report 13)

4.1.1.2 Supporters. The lexical choices that label the supporters of the Egyptian President can be grouped into six main sub-categories in the NYT and four sub-categories in $A O$ as shown in Table 4.2.






$\begin{array}{cllllllllllll}\text { NYT } & 47 & 20.17 \% & 125 & 53.65 \% & 16 & 6.87 \% & 19 & 14.8 \% & 7 & 3.00 \% & 8 & 3.43 \% \\ \text { AO } & 43 & 33.6 \% & 47 & 36.7 \% & --- & --- & 19 & 14.8 \% & --- & --- & 19 & 14.8 \%\end{array}$

\section{Table 4.2 Labeling Supporters in The New York Times \& Ahramonline Reports}

The Neutral category is assigned to phrases like "the President's supporters," "Egyptian President backers." In the second, third and fourth sub-categories, the words "Islamists," "allies" and "MB (i.e. Muslim Brotherhood) members" are used respectively in the reports. Negative words like "captors," "enforcers," "vigilante jailers," "attackers" are used in the NYT. The last sub-category is represented in naming supporters such as "Magdy Hamed, 47, a business man and a member of Brotherhood's party," (NYT) and "Mahmoud Ghozlan, official spokesperson of the Muslim Brotherhood" $(A O)$.

The results of analyzing the frequencies of the lexical items that are chosen to label and collocate with the President's supporters might reflect an ideological standpoint. The sub-category of the highest frequency (53.65\% NYT) and (36.7\% $\mathrm{AO})$ is labeling the supporters as "Islamists." This is revealing since, according to Collins Online English Dictionary, the word "Islamist" refers to "an advocate or supporter of Islamic militancy or fundamentalism." Therefore, the defining label is the one that implies negative connotations, especially for the foreign readers. This label presents an example of 'overlexicalization', a strategy defined by Fairclough (1989) as "an unusually high degree of wording, often involving many words which are near synonyms and shows preoccupation with some aspects of reality" (p. 15). Thus, the newspapers evaluate the President's supporters by categorizing them as one 'de-individualized' cluster. According to Teo (2000), "selecting and repeating a particular attribute assigned to a news actor points out to an underlying ideology that might have motivated the choice in the first place" (p.16). The frequent use of the label "Islamists" prompts the readers to interpret the supporters' actions by drawing upon a particular stereotype that associates them with violence.

Invoking Fairclough's (1995a) view that news actors can be referred to either individually or collectively, the newspapers apply both techniques in referring to the supporters. However, when they choose to refer to number of individuals who support the Constitutional Declaration, the newspapers adopt a strategy of "generalization" (Teo 2000, p. 16) to make them appear collectively as a loyal and obedient sect that cannot think individually. This strategy is further enhanced in view of the fact that whenever the newspapers introduce some names 
of the supporters $(3.43 \% N Y T)$ and $(14.8 \% A O)$, they attach to almost all the names a phrase that indicates their affiliation to the Muslim Brotherhood. This incites readers to view them collectively as followers rather than individual thinkers. Furthermore, only the NYT uses direct negative labels to refer to the supporters who attacked the opposition members around the Presidential palace with a frequency of (3\%). Direct negative labels such as "captors," "attackers" and "law enforcers" are strategically used by the newspaper to abate the readers' sympathy by presenting the supporters as aggressors.

Since almost all the supporters of the Constitutional Declaration are "Islamists" who either support or belong to the Muslim Brotherhood, it is useful to portray how the newspapers refer to the Muslim Brotherhood. This is exemplified as follows:

1. The Brotherhood is an insular, authoritarian movement shaped by decades as an underground secret society... (NYT Report No. 2)

2. ... group that has put its narrow party interests above the national interest (AO Report No.3)

Both newspapers seemingly seek to maintain a relationship of solidarity with the readers who share similar values against the MB. This is achieved by adopting two important strategies. First, "delegitimation" that is described by van Dijk (1993) as "a reference to the illegal activities and illegitimate status that are associated with the target group in order to enhance its negative portrayal and trigger negative emotions towards the group" (p.107). Therefore, by insisting on showing the link between the Egyptian President and the Brotherhood and asserting that the President's supporters are mostly Islamists who either belong to the group or other "ultraconservative" Islamist groups in Egypt, the ideological standpoint of both newspapers from the President and his supporters becomes clear.

Another important strategy used to portray the MB negatively is referred to by van Dijk (1993, p.258) as "over-completeness." It refers to what he calls "functional irrelevance" where relatively irrelevant information is given to convey a negative picture of a news actor. So, insisting on words like "Islamists" in a political event is purposefully over-complete.

4.1.1.3 Opponents. The lexical references used to refer to the opponents of the Egyptian President and his decisions are grouped into the subcategories as shown below: 


\begin{tabular}{|c|c|c|c|c|c|c|c|c|c|c|c|c|}
\hline \multirow{2}{*}{ 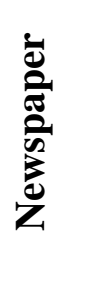 } & \multicolumn{2}{|c|}{ Neutral } & \multicolumn{2}{|c|}{$\begin{array}{l}\text { Ideological } \\
\text { Background }\end{array}$} & \multicolumn{2}{|c|}{ Opinion } & \multicolumn{2}{|c|}{ Victims } & \multicolumn{2}{|c|}{$\begin{array}{c}\text { Negative } \\
\text { (Accusations) }\end{array}$} & \multicolumn{2}{|c|}{ Names } \\
\hline & No. & $\%$ & No. & $\%$ & No. & $\%$ & No. & $\%$ & No. & $\%$ & No. & $\%$ \\
\hline NYT & 353 & $63.71 \%$ & 127 & $22.92 \%$ & 5 & $0.90 \%$ & 8 & $1.44 \%$ & 26 & $4.69 \%$ & 35 & $6.31 \%$ \\
\hline $\mathrm{AO}$ & 277 & $65 \%$ & 82 & $19.2 \%$ & 4 & $0.9 \%$ & --- & --- & 11 & $2.6 \%$ & 52 & $12 \%$ \\
\hline
\end{tabular}

Table 4.3 Labeling Opponents in The New York Times \& Ahramonline Reports

While opponents are described neutrally in both newspapers as "protesters," "demonstrators," "Egyptians," "revolutionaries" and "activists," they are represented ideologically as "secular protesters," "leftist(s)," "liberal(s)," "antiIslamists" and "boycotters." The NYT is more direct in labeling the opposition members as "victims," "captives" and "detainees" to indirectly evoke readers' sympathy with them. The Opinion subcategory involves epithets such as "newly formed/unified opposition," "fructuous/fractured' opposition," "pro-democracy opposition." Negative accusations are represented in "the remnants of Mubarak's now-defunct National Democratic Party," "old regime troublemakers," "liberal whiners," "Mubarak loyalists."

Two remarks should be made here. First, opposition members are mentioned 554 times in the $N Y T$ and 426 times in $A O$, substantially exceeding occurrences of supporters ( 233 times in NYT and 128 times in $A O$ ). This coverage of the opposition is also intensified by referring to almost 35 different individuals of the opposition figures against only 8 supporters in the $N Y T$ - and 52 individual opponents in $A O$, as opposed to 19 supporters. Second, the opposition members belong to different segments of the Egyptian society with different genders, religions, educational levels, social classes and ideological backgrounds such as: "Ghada, a 37-year-old attorney," "Marianne, a 19-year old student," "a former Egyptian diplomat Yehia Negm," Mohamed El-Aswany, an Al-Azhar cleric," "Human rights lawyer Gamal Eid." The discrepancy here might be intended by the newspapers in order to stress the individuality of the opposition figures and the grass-roots rejection of the President's Constitutional Declaration by contrasting the opposition to the supporters who are mostly referred to as members of the Muslim Brotherhood.

The adjectival collocate "secular" is used to pre-modify the noun "opposition" with a frequency of $9.74 \%$ in the NYT as contrasted with the label 
"Islamist" in referring to the supporters. According to Oxford English Online Dictionary, the term "secular" refers to a person who is "not connected with religious or spiritual matters." Thus, the repeated use of this label, which has a positive connotation to the foreign reader, is also used to canvass support of the readers and make them relate to the opposition and take their side as representing the moderate, non-fanatic part of the struggle.

\subsubsection{Reference to the Major News Events}

4.1.2.1 The Constitutional Declaration. Labelling the first event, the Constitutional Declaration, is shown below:

\begin{tabular}{|c|c|c|}
\hline Labelling & $N Y T$ & $A O$ \\
\hline Neutral & $\begin{array}{l}\text { - A decree } \\
\text { - Edict } \\
\text { - Decision }\end{array}$ & $\begin{array}{l}\text { - Constitutional Declaration } \\
\text { - Decree }\end{array}$ \\
\hline Positive & $\begin{array}{l}\text { An attempt to end the } \\
\text { transitional period }\end{array}$ & $\begin{array}{l}\text { - A revolutionary decision } \\
\text { - a legitimate move }\end{array}$ \\
\hline Negative & $\begin{array}{l}\text { - An absolute } \\
\text { Presidential } \\
\text { tyranny } \\
\text { - A horrifying coup } \\
\text { against legitimacy }\end{array}$ & $\begin{array}{l}\text { - Coup } \\
\text { - 'fascist' measures } \\
\text { - a major blow to the } \\
\text { revolution }\end{array}$ \\
\hline $\begin{array}{l}\text { The } \\
\text { lewspaper's } \\
\text { udgement }\end{array}$ & $\begin{array}{l}\text { His recent decree } \\
\text { whose Orwellian } \\
\text { language giving him } \\
\text { ill-defined powers to } \\
\text { protect the revolution }\end{array}$ & $\begin{array}{l}\text { - President Morsi's } \\
\text { controversial decree } \\
\text { - President's divisive decree }\end{array}$ \\
\hline
\end{tabular}

Table 4.4 Labeling The Constitutional Declaration in The New York Times \& Ahramonline Reports

Both newspapers assign more negative labels to describe and evaluate the Constitutional Declaration than neutral and positive ones. Adjectival collocations such as "autocratic," "sweeping," "extralegal," "unlawful," "aggressive," "unchecked," "dictatorial," "regressive" and "authoritarian" are frequently found Journal of Scientific Research in Arts (Language \& Literature) 5 (2021) 
in the news reports of both newspapers to collocate with the Constitutional Declaration.

The NYT ideological standpoint vis-à-vis the Declaration is reflected in the direct criticism found in Report no. 15 commenting on the decree's "Orwellian language giving him ill-defined powers to protect the revolution." Citing the President's supporters who defend the Declaration, the newspapers also strategically choose to insert few positive labels that collocate with the Constitutional Declaration, such as "an attempt to end the transitional period as soon as possible" and "an example of the enforcement of God's law."

4.1.2.2 Protests and the Presidential Palace events. The second major news event in the data is the protests triggered by the Constitutional Declaration. These protests led to deadly clashes between supporters and opponents of the Constitutional Declaration in front of Al-ittihadiya Presidential palace in Cairo. The following table presents labels used by the $N Y T$ and $A O$ in this respect.



AO

- Public expression of opinion

- (Massive) Protest(s)

- Demonstrations

- Wednesday massacre

- (Intense/bloody/deadly/street)

Clash(es)

$-\ldots$ more clashes will take place after the

Morsi's decision to dismiss the public prosecutor

Mr. Morsi's Islamist supporters detained and abused dozens of opponents

\section{Table 4.5 Labeling the Protests in The New York Times \& Ahramonline Reports}

Both newspapers communicate to their readers via different labels the neutral and peaceful nature of the protests that soon converted into bloody clashes. The 
newspapers also foreground the Egyptian President's Constitutional Declaration as the primary motivation for these clashes. The newspapers' view of the President's supporters as the initiators of violence is communicated to the readers through the direct labelling of the supporters as the group who "attacked" and "detained" the "opposition" and "opponents."

\subsection{Schematic Analysis}

The analysis shows significant differences in the schematic structure of the two newspapers. Almost all news reports of The New York Times are conventionally structured. Each news report presents a summary (headline + lead) followed by the representation of the main event. After the presentation of the main events, the newspaper represents the reactions of both sides on the events together with some background information. The newspaper also presents several instances of its evaluations on the major news actors and events. On the other hand, there are several variations and omissions of some of the formal categories in Ahramonline. Despite the fact that each news report begins with a clear headline and lead paragraph, some $A O$ news reports are too short, featuring a single episode or portraying the reactions of only one news actor. In fact, this difference in the schematic structure of the two newspapers can be interpreted as a consequence of $A O$ producing several news reports per day, unlike the $N Y T$ that produces only one report each day. The following subsections present the analysis of the four major categories of news schemata.

\subsubsection{The Summary/ Nucleus}

The Summary/Nucleus represents the highest macro-proposition in the news reports' schematic structure. This category includes headlines and lead paragraphs that give the idea of the story. Teo (2000) asserts that "headlines often encapsulate the newspaper's ideological values and attitudes" (p. 14). Table 4.6 presents some headlines.

\begin{tabular}{ccl} 
Report No. & Date & \multicolumn{1}{c}{ The New York Times } \\
1 & $22-11-2012$ & $\begin{array}{l}\text { Citing Deadlock, Egypt's Leader Seizes New Power and Plans } \\
\text { Mubarak Retrial }\end{array}$ \\
2 & $23-11-2012$ & $\begin{array}{l}\text { Clashes Break Out After Morsi Seizes New Power in Egypt } \\
\text { Egypt Protesters Gather to Denounce Morsi in Scenes Recalling } \\
6\end{array}$ \\
$27-11-2012$ & $\begin{array}{l}\text { Uprising } \\
\text { Morsi Defends Wide Authority as Turmoil Rises in Egypt }\end{array}$
\end{tabular}




$\begin{array}{ccl}\begin{array}{c}\text { Report No. } \\ 1\end{array} & \begin{array}{c}\text { Date } \\ 22-11-2012\end{array} & \begin{array}{l}\text { Ahramonline } \\ \text { Morsi declaration hailed by supporters, deemed 'coup' by } \\ \text { opposition } \\ \text { Thousands fill Tahrir on Friday to protest Morsi's new } \\ 2\end{array} \\ 23-11-2012 & \begin{array}{l}\text { 'dictatorial powers' } \\ \text { Blood Is Shed as Egyptian President's Backers and Rivals } \\ \text { Battle in Cairo } \\ \text { Morsi: } \text { A polarising figure in Egypt's referendum }\end{array} \\ 24 & 5-12-2012 & \end{array}$

\section{Table 4.6 Headlines of The New York Times and Ahramonline Newspapers}

President Morsi is thematized but negatively represented as a claimer of "wide authority" since he "seizes" illegitimate "dictatorial powers" by his Constitutional Declaration that is perceived as a "coup" against the rule of law. Ahramonline portrays him as a "polarizing figure," being the initiator of the protests in the Egyptian streets that resulted in "clashes" where "blood is shed."

The portrayal of the President's supporters in the NYT headlines is characterized by violence. They are only described in processes relevant to battling and abuse. Despite the use of the passive structure "blood is shed" to avoid direct attribution of responsibility and blame, the $A O$ foregrounds "President backers" to precede "rivals" in an implicit manifestation that the supporters are the instigators of the clashes. $A O$ headlines, however, appear less direct in their negative portrayal of the President's supporters. Aside from the newspaper's purposeful selection of the verb "hailed" to describe their reaction to the President's "dictatorial" declaration, it prefers to present the opposition's labelling of the event as a "coup" through direct quotations.

Therefore, the images that are suggested by the lexical and structural choices of the headlines portray the Egyptian President and his supporters as negative agents, unlike the opponents who are represented neutrally. This finding is further emphasized through the wording of the lead paragraphs exemplified below.

\section{Examples from the NYT:}

\section{Tens of thousands of people filled the central Tahrir Square on Tuesday} afternoon in an outpouring of rage at President Mohamed Morsi's attempt to claim expansive new powers ...(Report no. 6)

2. Angry mobs of Islamists battled secular protesters with fists, rocks and firebombs in the streets around the Presidential palace for hours Wednesday night... (Report no. 14) 


\section{Examples from $\mathrm{AO}$ :}

1. Opposition groups call for mass marches on Tuesday against Morsi's decision to grant himself nearly unlimited new powers (Report no. 3)

2. Demonstrators in support of the President and his recent constitutional decree chanted for the implementation of Islamic sharia ... (Report no. 10)

The lead paragraphs are structured in such a way as to purport a negative portrayal of the Egyptian President and his supporters. This is reflected through the syntactic structure that deliberately foregrounds the supporters in the frontal position of transitive active material processes that denote battling the opposition. The newspaper extends the portrayal in the readers' mental models through the vivid description in the prepositional phrases "with fists, rocks and firebombs ..."

Unlike the direct negative representation of the Egyptian President and his supporters in the lead paragraphs of the NYT, Ahramonline introduces more indirect evaluations in the lead. Neither the President nor his supporters are represented as direct agents in violence and aggression. Nevertheless, his Constitutional Declaration is described as a "decision to grant himself nearly unlimited new powers." Opposition figures are represented neutrally as "political opposition" that represents "Parties, groups from across Egypt's" (Report No. 5). Supporters, however, are represented as "hardline Islamist group" (Report No. 12) who are supporting the President only for "the implementation of Islamic sharia," which implies negative judgement by the newspaper. Therefore, foregrounding such propositions in the highest level of the thematic macrostructure of the news reports reflects the newspaper's standpoint which the uncritical reader would grasp as an unchallengeable fact (Fairclough 1995a, p.121).

\subsubsection{Main Events}

The main events of each news report are ordered according to the "relevance principle" (van Dijk 1988) that suggests that the most important events are portrayed first while the least are backgrounded. The presentation of the main events in the two newspapers sheds light on some similarities and differences between them.

It has been generally noticed that $N Y T$ reports foreground the negative aspects of the President's Constitutional Declaration and the rejection of the Constitutional Declaration by many Egyptians. They also foreground the defense of the President's supporters and officials who try to interpret the declaration in various ways to refute accusations of tyranny and the President's alleged intention to immune his decisions from the control of the judiciary. On the other hand, the 
presumably positive part of the Constitutional Declaration that deals with the replacement of the Mubarak-era Public Prosecutor and ordering retrials for former President Hosni Mubarak and other officials who were accused of killing civilian protesters during the 25th of January 2011 revolution is backgrounded to appear in the final paragraphs of the news report. Thus, the newspaper deliberately chooses to foreground the piece of information that stirs negative attitudes and judgements toward the Egyptian President and background other information that might result in some positive evaluations by the readers.

Unlike the NYT, $A O$ generally portrays the mass protests by the opposition following the Egyptian President's Constitutional Declaration. The various views of opposition members criticizing the declaration are foregrounded as main events with an almost absence of reference to the supporters' views. In its first report, however, $A O$ presents all the articles of the Egyptian President's Constitutional Declaration as one episode followed by the different reactions of both sides. In other $A O$ reports, the various views of opposition members criticizing the declaration are foregrounded as main events with scant reference to supporters' views. On the other hand, other events that might instigate the readers' sympathy with supporters' stance or justification of the President's acts are backgrounded or omitted in some reports.

\subsubsection{Background}

The Background category sheds light on the historical, political or social context or conditions of the actual news events. It is subdivided into two categories; Context and History. Context refers to the general socio-political states of affairs, or current events during which the specific event takes place, while History stretches back to certain period before the main events.

The analysis of the news reports reveals that the newspaper includes some paragraphs that divert from the main events for ideological purposes to highlight background past or current events that direct the readers' interpretation toward a particular end. Sometimes these paragraphs activate background knowledge in the memory of the readers to contextualize the meaning of the text in a particular way. This is exemplified as follows:

1. The crisis over his power grab came just days after the Islamist leader won international praise for his pragmatism, including from the United States, for brokering a cease-fire between Hamas and Israel. (NYT Report no.2)

2. Anger against Morsi ... has many sources and is related to a series of events. One clear source is the continued decline of socio-economic conditions in Egypt. 
Another source is the continued decay of public services that was tragically demonstrated by a road/rail disaster earlier this month that left close to 60 children dead. (AO Report no.6)

The explicit praise of the President's "pragmatism" by the United States is presented as background information to indirectly criticize the President's decision. The $A O$ report in (2) diverts from the main event into other sources that cause people's rage.

\subsubsection{Evaluation}

The final optional category in news reports' schematic structure is the Comments category. van Dijk (1988) introduces an Evaluation subcategory under the Comments category where the journalist "...explicitly formulate opinions (personal ones or those of the newspaper) about the actual news events" (p.167). Presenting the newspaper's evaluations on particular news events makes the newspaper appear more as a persuasive genre than informative hard news genre. Newspapers implicitly impose their evaluation either within the structure of the news reports or by the end of the report. As the examples below show, these evaluations and interpretations are mostly accepted by readers as a matter of fact and influence their interpretation of events.

1. ... Mr. Morsi's gesture was another demonstration that Egyptians would no longer allow their rulers to operate above the law. (NYT Report 5)

2. Mr. Morsi's decree has played into decades-old fears of the Brotherhood as an insular, authoritarian movement shaped by decades as an underground secret society.(NYT Report 2)

3. President Mohamed Morsi offered to limit the prerogative he had bestowed upon himself on 22 November through a constitutional declaration that prompted a nationwide outcry against the text's dictatorial spirit. (AO Report no.19)

These examples show that the NYT assumes a persuasive role against the Egyptian President's Declaration through inserting specific comments on the events. This technique helps in reproducing and sustaining dominant anti-Islamist ideology in the west that influences the readers' interpretation and evaluation of the situation in Egypt.

Therefore, the previous analysis presents evidence that the two newspapers share a similar evaluative stance for the major news actors and events. The analysis of the newspapers' schematic structure reflects various deliberate choices that have powerful impact in directing the readers' perception toward a particular interpretation of the major news events and actors. 


\section{Conclusion}

This paper investigated the lexical and schematic features of news reports issued by The New York Times and Ahramonline focusing on former President Mohamed Morsi's Constitutional Declaration and the protests that erupted as a result. The major news actors and events are evaluated through the use of 11 lexical strategies. Applying the CDA tools to the selected reports aimed at dissecting the linguistic and ideological strategies used by both newspapers to inculcate their readers with certain ideological standpoints to affect their judgments and beliefs.

This importance of this study arises from the fact that is the first to analyse the discourse of pre-revolutionary protests sparked by late President Mohamed Morsi's Constitutional Declaration. Adopting a micro-/macro, lexico-schematic level of analysis was not preceded in any of the studies we came across and was helpful in reaching our findings. Despite such plethora of CDA studies and their ramifications, no study - to the best our knowledge - tackled President Morsi's Constitutional Declaration and the ensuing protests outside the presidential palace. By choosing this topic, we hope that it would fill in a gap in studying the foreign and national electronic newspaper representations of this watershed event.

The analysis investigated both the lexical (micro-level) and schematic (macro-level) features of the news reports. It has been shown that both newspapers show more similarities than differences in the lexical choices, although the NYT is more direct in its evaluation. Discussion revealed that both newspapers abide by the formality rules in referring to the Egyptian President in the highest frequency with formal/neutral labels. However, both newspapers adopt a strategy of indirect evaluation by referring to the President's ideological background as a former member of the $\mathrm{MB}$ - a group that is negatively portrayed by both newspapers through the strategies of 'delegitimation' and 'over-completeness'. The supporters of the Egyptian President are represented negatively by both newspapers by means of three lexical strategies: 'overlexicalization', 'generalization' and 'negative labels'. On the other hand, both newspapers positively portray the opponents of the Egyptian President by manifesting their individuality and diversity to reflect all the factions of the Egyptian society rather than a single group.

Both newspapers choose to insert negative labels that defame the Constitutional Declaration and present it as an act against democracy and the rule of law. Though labelled neutrally in some cases, the protests were sometimes associated with negative adjectival collocations and appellations. 
On the schematic level, the analysis exhibits similarities in the categories of Summary, Background and Evaluation, and differences in the portrayal of the Main Events category. The reports of both newspapers show a standard structure but with significant variations. Almost all NYT news reports are conventionally structured. Nevertheless, several episodes are foregrounded while others are backgrounded - all on ideological grounds. The NYT presents several instances of direct evaluative comments on the major news actors and events that crystalize its ideological standpoint. On the other hand, there are several variations and omissions of some of the formal categories in $A O$. Despite the fact that each news report begins with a clear headline and lead paragraph, some news reports are too short, featuring a single episode of main events or portraying the reactions of only one side of news actors with less direct evaluative comments. It is assumed that the difference in the schematic structure of the two newspapers is ascribed to the prolificity of $A O$ reports against the $N Y T$ single-report-per-day coverage. It is also due to the fact that $A O$ is a state-owned newspaper while the $N Y T$ is an independent newspaper which is entitled to its own views and opinion, a luxury the $A O$ does not have. This also accounts for the $A O$ tending to avoid direct evaluative reporting - since the major news actor is the head of the state - and present a seemingly balanced informative reporting while implicitly inserting its evaluative stance within the structure of the news reports and within the purposeful selection of particular lexical variations in the headlines and lead paragraphs.

The analysis of the Main Events category shows more differences than similarities in the representation by the two newspapers. The NYT is more direct in reflecting its ideological standpoint by ordering the episodes of the main events according to the "relevance principle." It chooses to foreground many episodes that thematize the negative portrayal of the Egyptian President and his supporters, and background other episodes that might invoke readers' justification of the President's acts. Many episodes are completely omitted in the representation of main events in $A O$.

In the Background category, both newspapers include many instances that divert from the main events to highlight certain events for ideological purposes. The Evaluation subcategory was implicitly inserted within the reports to make them accepted by the readers as indisputable facts. Although Harcup and Cole (2010, p.1) argue that newspapers should present information to the readers "in an honest and balanced way," this aim, often hindered by ideological strategies and orientations, seems too difficult to achieve. 


\section{References}

Alhumaidi, M. (2013). A critical discourse analysis of Al-Ahram and Aljazeera's online coverage of Egypt's 2011 revolution [Doctoral dissertation]. ProQuest Dissertations and Theses database. (UMI No. 3584272)

Almustafa, A. (2016). Critical discourse analysis of news reports of the Libyan revolution in Arabic versus foreign coverage [Unpublished Doctoral dissertation, Helwan University, Egypt]

Bassiouney, R. (2012). Politicizing identity: Code choice and stance-taking during the Egyptian revolution. Discourse \& Society, 23(2), pp. 107-26.

Bhatia, A. (2006). Critical Discourse Analysis of political press conferences. Discourse \& Society 17, no. 2, pp. 173-203

Bichang'a, W. \& George, A. (2012). Kenyan media discourse: A critical discourse analysis of news headlines on 2007 election campaigns. Journal of Education and Social Sciences, 1(2), pp. 42-55.

Blommaert, J. \& Bulcaen, C. (2000). Critical discourse analysis. Annual Review of Anthropology, 29, 447-466.

Cabaniss, E. R. (2006). All the news that's fit to print: the social construction of the American immigrant by The New York Times, 1892-1924 [Master's thesis]. ProQuest Dissertations and Theses database. (UMI No. 1436038)

Chilton, P. (2004). Analysing Political Discourse. Theory and Practice. Routledge.

Chouliaraki, L. (2008). The Media as moral Education: Mediation and action." Media, Culture \& Society 30, no. 6, pp. 831-852.

Cotter, C. (2001). Discourse and media. In D. Schiffrin, D. Tannen \& H. E. Hamilton. (Eds.). The Handbook of Discourse Analysis. Blackwell Publishers, pp. 416-436.

Davies, B. and Harré, R. (1990). Positioning: The discursive production of selves, Journal for the Theory of Social Behavior, 20(1), pp. 43-63.

Eggins, S. (2004). An introduction to Systemic Functional Linguistics. 2nd edition. London \& New York: Continuum international publishing group.

Fairclough, N. (1989). Language and Power. Longman.

Fairclough, N. (1995a). Media Discourse. Edward Arnold.

Fairclough, N. L. (1995b). Critical discourse analysis: The critical study of language. Harlow, UK: Person.

Fairclough, N. \& Wodak, R. (1997). Critical discourse analysis. In T.A. van Dijk (Ed.), Discourse as Social Interaction (pp. 258-284). Sage. 
Farmanfarmaian, R. (2014). Policing the Arab Spring: Discordant discourses of protest and intervention. In Riot, Unrest and Protest on the Global Stage (pp. 277-300).

Fowler, R., \& Kress, G. (1979). Critical linguistics. In R. Fowler, B. Hodge, G. Kress, \& T. Trew (Eds.), Language and control (pp. 185-213). Routledge.

Fowler, R. (1991). Language in the news: Discourse and ideology in the press. Routledge.

Fowler, R. (1996). On critical linguistics. In C.R. Coulthard \& M. Coulthard (Eds.), Texts and practices: Readings in critical discourse analysis (pp. 314). Routledge.

Ghobrial, B. G., \& Wilkins, K. G. (2015). The politics of political communication: Competing news discourses of the 2011 Egyptian protests. International Communication Gazette, 77(2), 129-150.

Hall, H. T. (2008). Brand Jane-Finch: A Critical Discourse Analysis of print media discourse on a Toronto low income community [Master's thesis]. ProQuest Dissertations and Theses database. (ISBN No. 978-0-494-459393)

Hall, S. (1996). The problem of ideology: Marxism without guarantees. In D. Morely \& K. Chen (Eds.), Stuart Hall: Critical dialogues in cultural studies (pp. 25-46). Routledge.

Hall, S. B. (2012). The discourse of protest: Using discourse analysis to identify speech acts in UK broadsheet newspapers. Media@ LSE, pp.1-55.

Harcup, T. \& Cole, P. (2010). Newspaper journalism. Sage Publications.

Hasan, M. (2016). A critical discourse analysis of translated news media texts: The case of Euronews channel [unpublished Doctorate dissertation, Cairo University, Egypt].

Islamist (n.d.). In Oxford English Online Dictionary. https://www.lexico.com/definition/islamist

Kim, K. (2014). Examining US news media discourses about North Korea: A corpus-based critical discourse analysis. Discourse \& Society, 25, 221-244. https://doi: 10.1177/0957926513516043

Kress, G. \& Hodge, R. (1979). Language as Ideology. Routlege

Kumar, A. (2001). Rewriting the Language of Politics: Kisans in Colonial Bihar. Monohar

Lean, M. L. (2008). New kids on the block: The discursive construction of two new premiers by the mass media. Critical Approaches to Discourse Analysis across Disciplines Journal, 2(1), 59-75. 
Linke, U. (2008). The language of resistance: Rhetorical tactics and symbols of protest in Germany', City and Society, 2(2), pp. 127-33.

Mayr, A. (2008). Introduction: Power, discourse and institutions. In A. Mayer (Ed.), Language and power: An introduction to institutional discourse (pp. 1-25). Continuum.

Moftah, A. (2013). A Critical Discourse Analysis of news reporting of the attack on the Syrian national security hq in the Egyptian Gazette and Tehran Times. Faculty of Arts Magazine, Helwan University, (34), pp.29-56.

Molek-Kozakowska, K. (2012). Multiple Ideologies in the Media Construction of Women in Politics: A Case Study of Gender Parity Debate in Poland. Critical Approaches to Discourse Analysis across Disciplines, 5(2). 72-87.

Moon, R. (2021). When Journalists See Themselves as Villains: The Power of Negative Discourse. Journalism \& Mass Communication Quarterly, 1077699020985465.

Nimmo, D. (1990). New directions in political communication: A resource book, SAGE Publications, Incorporated, 1990, p. 116.

Oktar, L. (2001). The ideological organization of representational processes in the presentation of us and them. Discourse \& Society, 12(3), 313-346.

Pan, Z., \& Kosicki, G. M. (1993). Framing analysis: An approach to news discourse. Political communication, 10(1), 55-75.

Pasha, T. (2011). Islamists in the headlines: Critical discourse analysis of the representation of the Muslim Brotherhood in Egyptian newspapers [Doctorate dissertation, The University of Utah]. ProQuest Dissertations and Theses database. (UMI No. 3262629)

Paulin, L. M. (2007). Newspaper discourses of Latino labor and Latino rights in the new United States South [Doctorate dissertation]. ProQuest Dissertations and Theses database. (UMI No. 3262629)

Retzlaff, S., \& Gänzle, S. (2008). Constructing the European Union in Canadian news. Critical Approaches to Discourse Analysis across Disciplines, 2(2), 67-89.

Richardson, J.E. (2007). Analyzing Newspapers: An approach from Critical Discourse Analysis. Palgrave Macmillan.

Riggins, S. H. (1990). Beyond Goffman: Studies on Communication, Institution, and Social Interaction. Mouton de Gruyter.

Said, S. B., \& Kasanga, L. A. (2016). The discourse of protest: Frames of identity, intertextuality and interdiscursivity. Negotiating and contesting identities in linguistic landscapes, 71-83. 
Schroder, K. C. (1994). Media language and communication. The encyclopedia of language and linguistics (Vol. 5, pp. 2412-20). Pergamum Press.

Secular (n.d.). In Oxford English Online Dictionary https://en.oxforddictionaries.com/definition/secular

Sheyholislami, J. (2001). Yesterday's "separatists" are today's "resistance fighters": A critical discourse analysis of the representation of Iraqi Kurds in The New York Times and the Globe and Mail (Master's thesis). ProQuest Dissertations and Theses database.

Shmargad, Y., \& Klar, S. (2020). Sorting the news: How ranking by popularity polarizes our politics. Political Communication, 37(3), 423-446.

Sian, K., Law, I., \& Sayyid, S. (2012). The Media and Muslims in the UK. Consultado a, 15, 2013.

Sonntag, S. K. (2003). The Local Politics of Global English. Case Studies in Linguistic Globalization. Lexington Books.

Teo, P. (2000). Racism in the news: A critical discourse analysis of news reporting in two Australian newspapers. Discourse \& Society, 11(1), 7-49. https://doi:10.1177/0957926500011001002

Tranchese, A., \& Zollo, S. A. (2013). The construction of gender-based violence in the British printed and broadcast media. Critical Approaches to Discourse Analysis Across Disciplines, 7(1) 141-163.

Ukeje, C. (2004). From Aba to Ugborodo: Gender identity and alternative discourse of social protest among women in the oil delta of Nigeria, Oxford Development Studies, 32(4), pp. 605-17.

van Dijk, T. A. (1983). Discourse analysis: Its development and application to the structure of news. Journal of communication, 33(2), 20-43.

van Dijk, T. A. (1988). News as Discourse. Lawrence Erlbaum Associates Inc.

van Dijk, T. A. (1991). Media contents: The interdisciplinary study of new as discourse. In K. B. Jenson \& N. W. Jankowski (Eds.), A handbook of qualitative methodologies of mass communication research (pp. 108-120). Routledge.

van Dijk, T. A. (1993). Principles of critical discourse analysis. Discourse \& Society 4(2): 249-283.

van Dijk, T. A. (1995a). Discourse, semantics and ideology. Discourse \& Society. 6 (2), 243-89.

van Dijk, T. (1998). Opinions and ideologies in the press. In Approaches to media discourse, edited by A. Bell and P. Garrett (Eds.), Approaches to media discourse. Blackwell, pp. 21-63. 
van Dijk, T. A. (2001) Critical Discourse Analysis. In Schiffrin, D., Tannen, D., \& Hamilton, H. E. (Eds.), The handbook of discourse analysis. Blackwell Publishers.

van Dijk,T. A. (2006). Politics, ideology and discourse. Encyclopedia of Language \& Linguistics (2nd ed., pp. 728-740). https://doi: 10.1016/b008-044854-2/00722-7

van Dijk, T. A. (2008). Discourse and power. New York: Palgrave Macmillan.

Wodak, R. (Ed.) (1989). Language, Power and Ideology: Studies in Political Discourse. John Benjamins.

Wodak, R. (2006). Critical linguistics and critical discourse analysis. In J-O. Östmann, J. Verschueren, \& E. Versluys (Eds.), Handbook of Pragmatics. John Benjamins.

Wood, A. G. (2000). Urban protest and the discourse of popular nationalism in postrevolutionary Mexico: The case of the Veracruz rent strike, National Identities, 2(3), pp. 265-76.

Woolfson, C. (2006). Discourses of labor protest, Atlantic Journal of Communication, 14(1/2), pp. 70-96.

Youssef, A. (2012). A critical analysis on media coverage of the Egyptian revolution: The case of Al-Ahram, Al-Masry Al-Youm, The Telegraph and The Washington Post (Master's thesis, Örebro University, Örebro, Sweden). https://www.divaportal.org/smash/get/diva2:540808/fulltext01.pdf

Yusha'u, M. J. (2012). Representation of Boko Haram discourses in the British broadsheets. Journal of Arab \& Muslim Media Research, 5(1), 91-108. 


\section{تحليل لفظي نسقي لتمثيل الاحتجاجات السياسية في مصر في "ذا نيويورك تايمز" و "الأهرام أونلاين"}

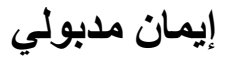 \\ قسم اللغات، كلية اللغة والإعلام، الأكاديمية \\ العربية للعلوم والتكنولوجيا والنقل البحري، الاكاليه \\ القاهرة
}

manno505@hotmail.com

\author{
محمد النشار \\ قسم اللغة والترجمة، كلية اللغة والإعلام، \\ الأكاديمية العربية للعلوم والتكنولوجيا والنئة والنقل

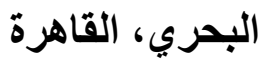 \\ melnashar68@gmail.com
}

المستخلص

تهدف هذه الدراسة إلى إجر اء تحليل نوعي وكمي لتمثيل الاحتجاجات التى حدثت في مصر في أعقاب

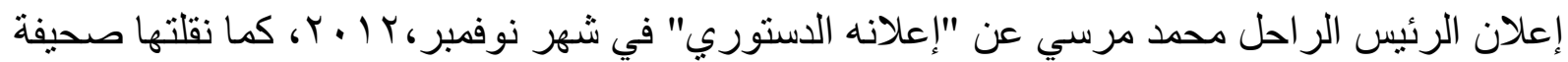



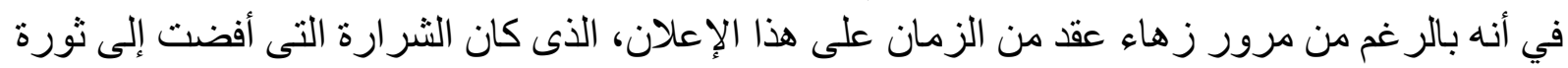

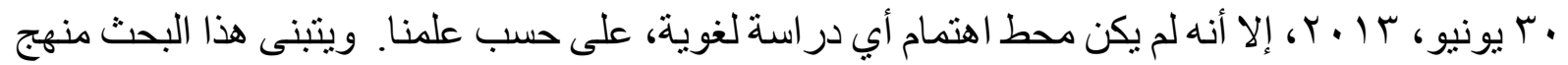

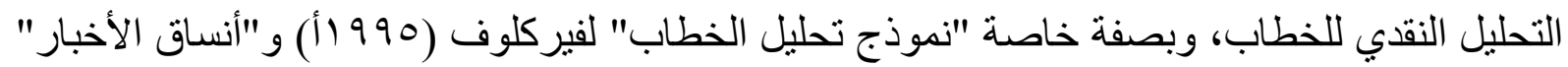

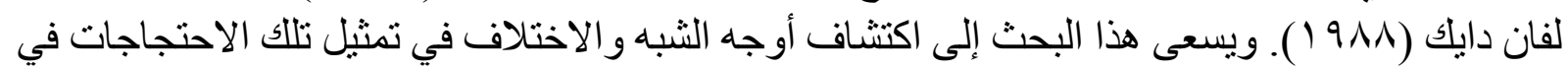

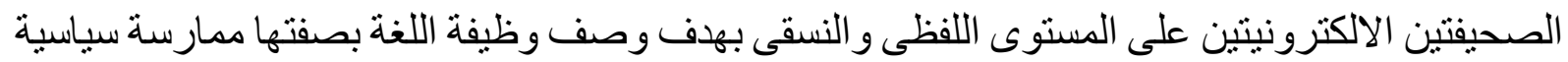

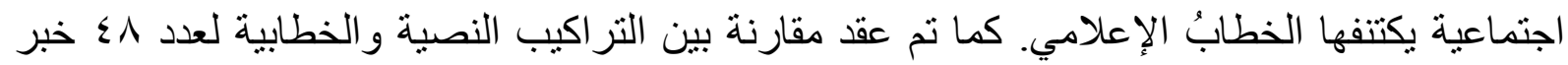





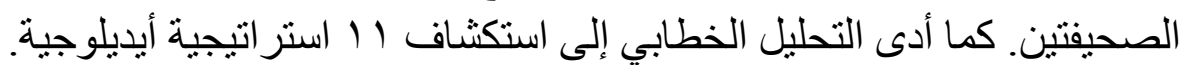

الكلمات الادلة: التحليل النقاى للخطاب، الخطاب الإعلامي، أنساق الأخبار، الإعلان الدستوري، الاحتجاجات في مصر، الأيديولوجية النفية 